\title{
麴室の改造について
}

W-II 型製绹方式—

\section{今 井武*}

\section{1. 麴室の位置と階段}

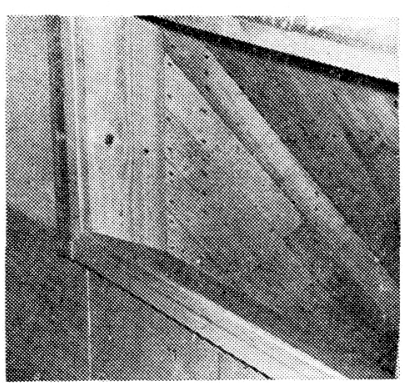

図 1 天空利用蒸米投入口 (表)

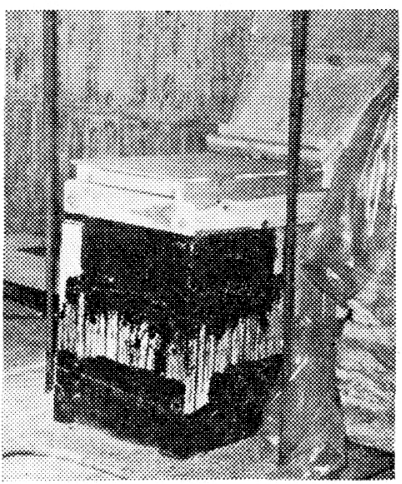

図 2 天空利用蒸米投入口 (裏) 来る。
酒造工程中人の動線 の中心は原料処理場で 岕る今仮りに一枚の 紙汇作業員の動線を画 いたならば，非常に無 駄な動さの多いのに驚 く。棦室と原料処理場 は近い与が便利で，南 西角厄室の位置がよ い。蒸米放冷場が室の 上の階にあれば天空の 一部利用で引込久る出

仕达藏の中二階はほ とえど利用されていな いことが多い。よく蔵 の狭さを訴える埜氏を 見受けるが，中二階比 木桶, 三尺桶, 小道具類 は恐らく十数年全く触 れたことのないるのが 添とんどと思う。物を 大切にすることは重要なことであるが，道具は使用価值 による。ただ単に保存していらだけでは場所をふさぐだ けである。整理をしたとえば隣接している酛場の壁をと り連絡するとか, 楚室との動線を考学ることにより合理 化される。二倲の二階建が平行して叔り中間に原料処理 場がある場合, 二階犬゙けの渡瑯下を幅約 $2 \mathrm{~m}$ 程度のもの そつくり, 㽀の位置等考虑し, それにT字型めるいは L 字型に階段を設けると整室, 酛場が二階の場合は一層利 用度が大きい。

麳室の広さは製楼方式により異なるが，藏の広い処で * 和歌山紧工業試験場
は従来の粐穀で充分である。しふし踏达む前に両面に防 水施工してから粐穀を充埧することである。麴室を改造 する際多量の粐穀を除去して始わて内部の柱が（特に棚 の整蓋が重ねられていた高さまで）腐蝕しているのに驚 かされる。防水は断熱効果を増すためにも木材腐蝕防止 にも必らず必要である。

断熱材については再三本誌にる揭載されているので略 すが，断熱と防水の点から最も優れているのはポリスチ ロール（スキロホーム）で，麴室の内部に露出張りが理 想であるが，軟かいため物があたると䭾目であるから天 井, 天空が最適と思引。スチロホームは少々高価でも市 るから必要外は安価な断熱材を選択すべきである。

麥米室の断熱材による内部有効率は，従来の粐穀使用は 約 60\% 前後，新断熱材では約 90\% 前後で, 1.5 倍て なること惊々のべられているが付記しておく。

\section{2. 天 空}

最近換気扇の発達は急速でその利用てより従来の天空 不要論まで出て自然通風式の妙味を疎じる傾向がある が，これにはいささか異論がある。換気扇の一部併用は 良策で安る。索た量天等自然通風の弱い時想定し岕る 程度多く天管を持つこと的一方法と考光る。

自然通風式天空の場合, 麳室つ内面積 $10 \mathrm{~m}^{2}$ 当天空の 延断面積, 排気筒 $700 \sim 750 \mathrm{~cm}^{2}$, 入気筒 $600 \sim 650 \mathrm{~cm}^{2}$

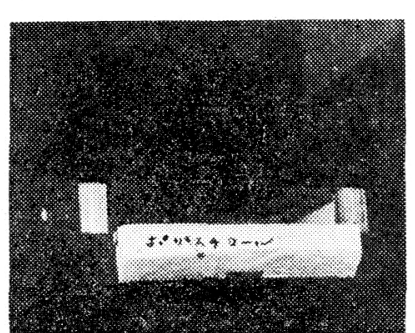

図 3 天窓ポリスチロ 一儿張付状況 とし，交互に排気，入 気, 独立乙て設置す る。1個つ単位は 900 $\sim 1,200 \mathrm{~cm}^{2}$ 程度が適 当で京る。

断熱施行済の天空に ポリスチロールの露出 内張は結露現象がなく 清潔である。

天空開閉とついては引戸型は完全閉鎖が出来ないので, 結露現象を起し絶えず, 湿潤状態で引戸の動きも悪く菌 


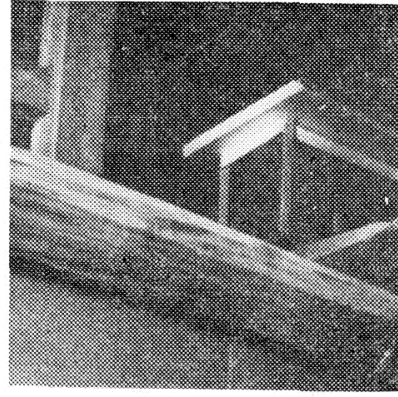

図4 屋根裏結露防止
学的にも不綮である。 蝶番付開閉扉 (箱型) とし, 天空の下に中吊 固定し，箱の内側にポ リスチャールを張り， 横枠の夕四方に開閉与 ると理想的で全く結露 現象もなく排気され， 入気以一度箱の底面に 当り四方に分散される

ので好結果を収めている。

排気筒上部の屋根裏に, しばしば結露現象を見受ける ので，屋根裏の直接湿潤空気の当る部分に布とか，ポリ スチャールを張ると効果的である。

\section{3. 出入口扉}

従来䊝室の出入口罪は踏込又の関係上必号ず前後二枚 設けられているが，内戸は活とんぞ簡単な引戸が多く， 外屝沖訳的注断熱材がつめられて，度々の開閉ショッ クにより充填斑を生じ結露現象を起しているが当然のこ

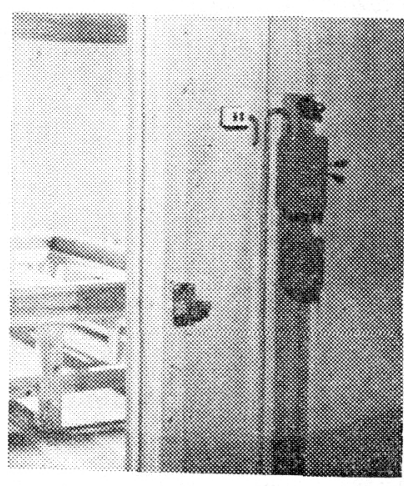

図 5 整室入口 1 枚屝 とで，あの狭い所に熱 湯の入った容器が置か れているがあまり感心 した方法ではない。外 屝を新断熱材に入れ替 えパッキングを完全に すれば内戸は不要で女 る。よく聞くことでめ るが二枚なけ机ば冷い 外気が直接入るので猌道 に悪いと云っているが, 実際操作を観察すると 一枚々々静かに開閉しているものがない。まだ内戸を完 全なパッキングそ使用断熱材を入れた屝とし外戸はある 程度粗末な扉式の概念の方が理窟にあっているが，無意 識的に実施していたことを反省せねばならない。

一枚の屝とした方が広く動き易くなる。

\section{4. 䊝蓋}

酒造りの道具の中で，型を同じくした員数の多いもの

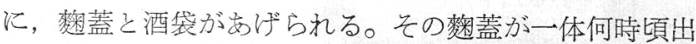
来たのふ，本県の酒の歴史家南方久雄氏（南方酒造株式 会社々長）によると，元禄時代すでに使用されたよ5 でもめり，また德川末期に出榃の使用区分のためにも一 升盛容器として使用されているが，本格的にはやはり明

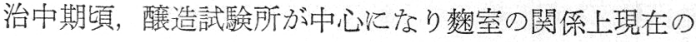

一升盛程度が良いということで，ある程度規格化された ようで岁る。

\section{（1）立体的利用}

断熱材として数穀を利用する場合は有効面積が極減す るので立体的利用がもっとも合理的である。

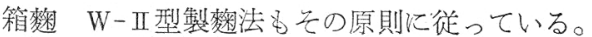

（口）精米歩合と品温調節

棶蓋が規格化された時代は，麴米の精米歩合は 90〜 $85 \%$ 程度で, 製整中の品温上昇が甚だしく品温調節に 苦労した結果, 共蓋の利用, 積替, 手入等の操作の最適 要領が合理的に定められたが，昨今のよ5に 70〜75\% 程度まで精米歩合が下れば，当時の品温上昇経過と在り 方を異にすべきで，現在の精米歩合とあわせて再検討の 要が岁ると思う。

\section{5. 温 床 線}

温床線は農業の合理化飞非常に活用され次第に応用範 囲が広くなり，育雊用だとかコンクリート差生，製塩等 に使用されて来た。本県に执いて, 昭和 35 年麥室に応 用乙て好成續を収め, 現在は過半数が実施している状況 である。

个. 火㷋予防

口. 温度分布が均一

八. 断熱保温の補助

まず火苂予防であるが，耐熱性ビニール被覆が発熱抵 抗線に施して女るから安全で, 它の線自体が $80^{\circ} \mathrm{C}$ 以下 の温度で使用することに基準が预かれ, 次のよ5 亿電圧 $(\mathrm{V})$, 電力 $(W)$, 発熱線の長さ $(\mathrm{m})$ が規定されている。

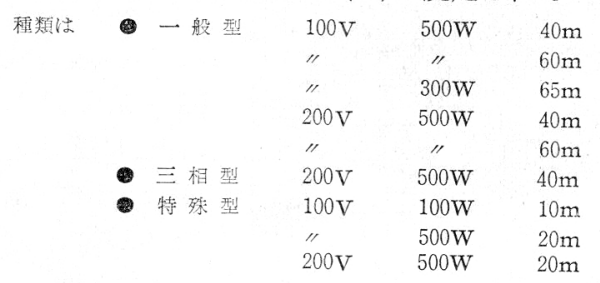

麳室の内壁下部に図6のよ5 6 亿配線するが，必要電力 容量と側壁の延長さにより，なるべく均等に配線するこ とが好委しいので, 一般型，离るいは三相型，特殊型を 組合わせることが大切である。

温床線の麳室住対する電力容量は, $33 \mathrm{~m}^{2}$ (10 坪) に $1.5 \mathrm{~kW}$ として設計基準を和くと充分で岕る。な拈サ一 モスタットを付設すれば理想的な温度管理が出来る。上 記の電力容量はやや安全率をみているなぬ不必要な場合 はサーモスタットルより切れるので合理的である。1/2 位でも整室の断熱が良好で岕れば，実用に支障はないが 寒さの甚しい場合, 室内乾燥の要女る場合はやはり上記

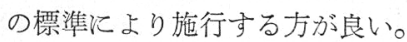




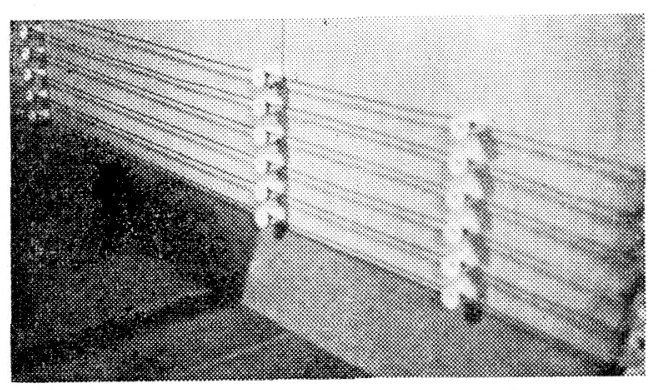

図 6 温床配 線

最下部の第一線は床面より $10 \mathrm{~cm}$ とし, 線間 3〜3.5 $\mathrm{cm}$ ，側壁との間隔 $2.5 \mathrm{~cm}$ 以上とし，がいしで $90 \mathrm{~cm}$

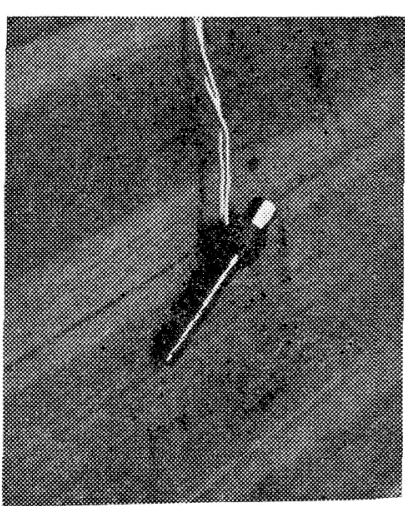

間隔程度で支持する。 実施の場合は電気工事 の会社と打合わせ，工 作物規程, 電気温床線 の施設の頃を吟味し遺 憾のないようにする。 温床線はなるべく一 般型を使用与る方方， 抵抗線の発熱分散白良 い。単相の場合は単線 配線で岕るから簡単で 岀るが，三相の場合は， 図 7 サーモスタット（ナショ ナルゴールドサーモ)

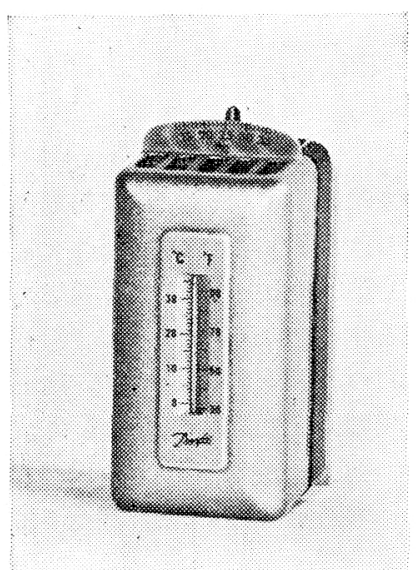

図 8 サーモスタット（ダンホ 一ス，ルームサーモスタッ 卜)

三相用を使用与れば最 も簡単で岀る。丁度テ レビアンテナのテープ 型コードのようになっ て，発熱抵抗線三本が $\mathrm{Y}$ 型結線され一端をビ ニール被覆で封じ他端 は三相キャップタイヤ が接続されているから 取扱いる容易でむる。 ただし線自体の温度分 散はやはり一般型の方 が良いと考光る。

一般型の場合は， $\triangle$ 型結線にして配線し要 領は同じで多る。

特殊型の場合は長さる短いため発熱線自体が温度分散 が遅れ温度が高いのでなるべくさけた方が良いと思う。

サーモスタットは種々出るが次の二種類が適当と思 50

$$
\begin{aligned}
& 1 \text { ナショナルゴールドサーモ } \\
& \text { 口 ルームサーモスタット（ダンホース） }
\end{aligned}
$$

$$
\begin{aligned}
& 15 \sim 35^{\circ} \mathrm{C} \text { (上昇断) } \quad ¥ 2,820 \\
& 10 \sim 25^{\circ} \mathrm{C} \text { (上昇断) } ¥ 2,550
\end{aligned}
$$

注。（ロ）のルームサーモスタットの方が僅かであるが 優机ているように思う。

サーモスタットを併用した場合はマグネットスイッチ は，三相の文必要なことは当然で岁る。

従来の㦿に断熱材を入れず，温床線 $100 \mathrm{~V} 300 \mathrm{~W} 65$ $\mathrm{m}$ 女るいは 100V，500W，40m を床板の裏に配線，サ 一モスタットを付汗て温度調節することも実施したが好 成績である。

\section{W-II 型製秉方式}

製麥米の合理化は自動製憗が理想であるが，従来の茂室 の一部改造により操作をより合理化することが急務と考

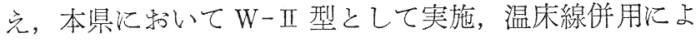
り一層実用的に利用度を高好結果を収めている。

床楼法は製槒操作の基本型式で，床椫台の切り方いか んにより箱棅式となり更に細分することにより棦蓋とな る。またたてに帯状に切れば，W-I 型及びW-II型方式 となる。

W-II 型は図 10 のよ5亿従来の䊝室の棚だけを改造 し，上記の帯状のbのを二段ベッド型式に組み，操作は

\begin{tabular}{|c|c|c|c|c|}
\hline & & I & 事 & 費 \\
\hline 木 & & & 材 & 28,000 円 \\
\hline 大 & 工 & 手 & 間 & 20,000円 \\
\hline 電 & 気 & I & 事 & 15,000 円 \\
\hline 雑 & & & 費 & 2,000円 \\
\hline 合 & & & 計 & 65,000 円 \\
\hline
\end{tabular}
床㮃法の場合と同様に乙簡素化することが特長である。 幅の標準はW-I型 $90 \mathrm{~cm}, W$ - II 型 $60 \mathrm{~cm}$ 程度とする。 実例として図 9，10，11 は 1.200kg 半仕舞（8石半

仕舞）のるので，相当狭いのを無理をしていたが，W一 II型を採用実施したため従来の $20 \%$ 増は容易となり，

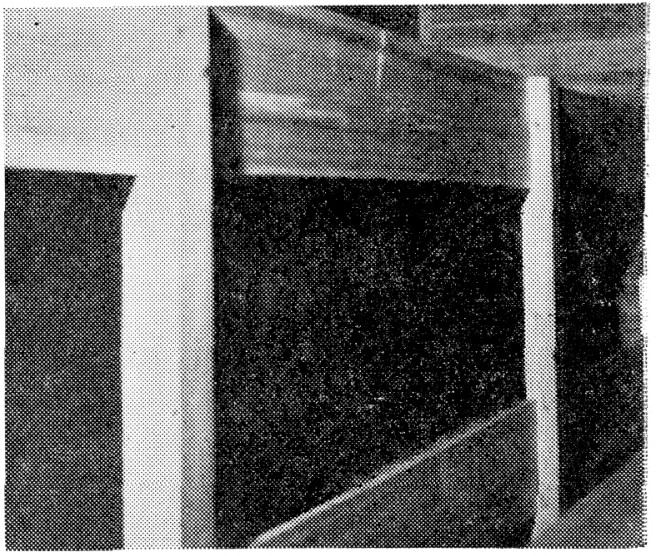

図 9 W II 型製整方式 


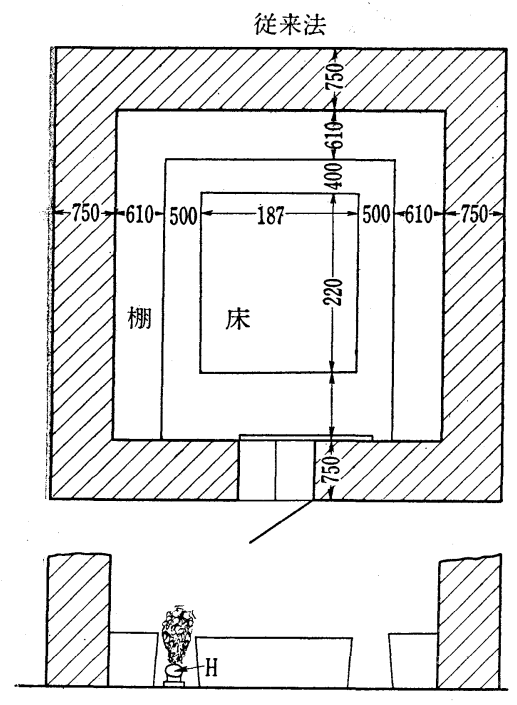

図 10 W II 型製敀方式
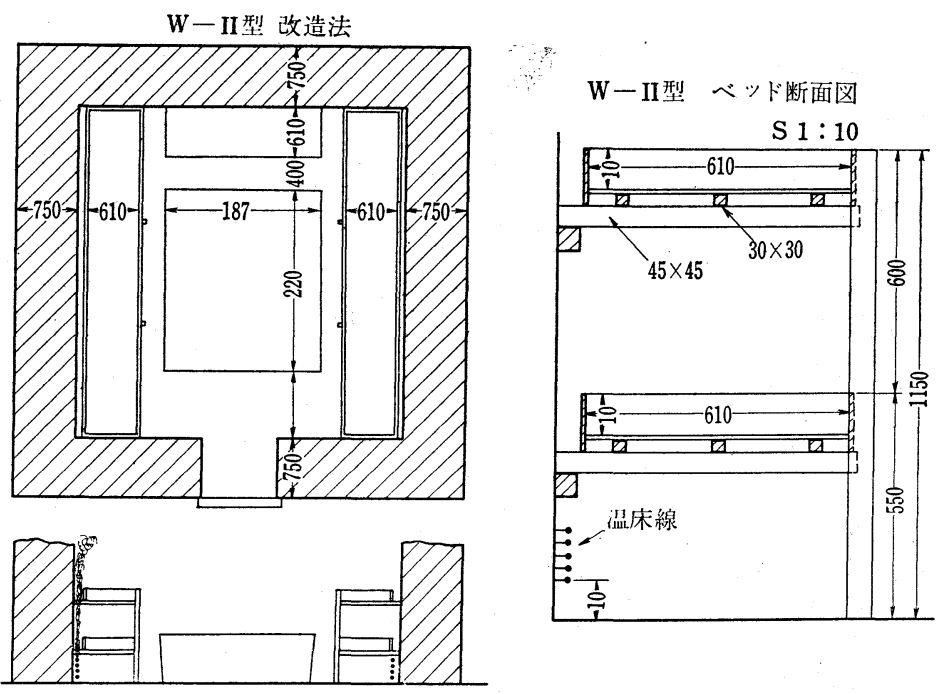

操作も合理化され好成績を収めた。従来の床は仕込量の 変更のない限り操作は可能であり, 盛り後仕舞仕事の占 める面積の在り方が設計基礎となる。

个所要面積 橎米 $150 \mathrm{~kg}$ 当 $9 \mathrm{~m}^{2}$

口 帯状ベッドの延べ長さ（幅 $61 \mathrm{~cm}$ として）

$9 \mathrm{~m}^{2} \div 0.61 \mathrm{~m}=14.75 \mathrm{~m} \rightarrow 15 \mathrm{~m}$

、剓室奥行（二段で両側にあるため）

$15 \mathrm{~m} \div 4=3.75 \mathrm{~m} \rightarrow 4 \mathrm{~m}$

故に奥行約 $4 \mathrm{~m}$ ある室では充分となり, 入口正面の棚の 上段に短いベッドを作れば更に引込みを増加出来るし下 の棚は床と同一幅とし板を渡して床の延長として利用す ると, 一石三鳥ともなる。

室の内壁の下部に温床線を配線しているため, 熱の分 布も良く側壁を熱が上昇するので保温効果を增してい る。その利点を利用するために, 二段ベッドの枠が側壁 と 6〜 $7 \mathrm{~cm}$ 隔たりを必要とする。

もらろんベッドの構造は床䊬の底と同様板笽をはる。 横枠は厚さ $1.8 \mathrm{~cm}$ 程度の杉板を使用し, 筫の面からの 有効深さを $10 \mathrm{~cm}$ に設計する。な特ベッド支柱は 1.4 $\sim 1.5 \mathrm{~m}$ 毎に半固定し上記木枠をはめ込み, 取りはずし

可能とする。筫も時々洗い清潔に保たねば，折角の合理 化も意義がなくなる。

ベッドの高さは図 11 のように一段目木枠の上部を床 面より $55 \mathrm{~cm}$ ，二段目はそれより $60 \mathrm{~cm}$ 上った所に木枠 上部が来, 下より $115 \mathrm{~cm}$ の高さとベッド幅 $60 \mathrm{~cm}$ 前後 を標準とする。

温床線はこの場合, 猌室内面積 $4 \times 4=116 \mathrm{~m}^{2}$ である から, 標準 $1.5 \mathrm{~kW} / 33 \mathrm{~m}^{2}$ より算出し, 約 $730 \mathrm{~W}$ となる が, 従来電熱器 $1.5 \mathrm{~kW}$ 使用しているため, 上記計算 より安全をみ $500 W 2$ 本が適当となる。単相, 三相は その場に応じ決定する。

狭い場所で休操作が出来難い場合は最近の図書館等の 本棚の整理法等レールをしき必要な棚え入る幅だけを確 保するようにスイッチで自動的になっているようで䊝室 の床もレールで移動可能とするのも合理化の一つである。 又出猌場合従来は出入口の利用のみであったが, 䊝室 の位置にもよるが麴枯し場の位置と, 人の動線を考兄 側壁又は床面に径 $30 \mathrm{~cm}$ 程度の孔をあけると, 出䴿も 簡単:操作が出来る。もちろん使用後の断熱は完全にす s。 